er ikke fordi den egentlig er underbetonet, men problemet ligger $i$, at det aldrig gøres klart, at i udgangspunktet stod teologien (den, om man vil, autoritative udlægning af, hvad kristendommen egentlig gik ud på) overfor en nærmest umulig opgave: den skulle støttet af et vokabular og en tankeform, der var hentet fra græsk og romersk filosofi - andet intellektuelt redskab havde man ikke klargøre og præcisere, hvad kristendommens grundantagelser, dens dogmer, gik ud på. Opgaven var næsten uoverkommelig, for den græsk- romerske filosofi havde en helt anden ontologi end kristendommen: her var verden ikke skabt, så lidt som "intet" fandtes. Men i kristendommen skabte Gud himlen og jorden ud af intet. Problemet var ikke først og fremmest - som det fremstilles - et problem omhandlende forholdet mellem tro og viden. Det var det også, men dybest set handlede det om at tilpasse det filosofiske vokabular, der var tænkt ind $i$ en helt anden ontologi til kristendommen: det kom der en græsk-romersk teologi ud af, som Luther en del år senere forsøgte at rette op på, lige som der kom en kristen Platon ud af det.

At bogen er en kulturhistorisk fremstilling, defineret som ovenfor citeret, kommer også til udtryk i et i øvrigt omfattende register til slut i bogen. Skønt registeret er omfattende, består det næsten udelukkende af personnavne og steder samt enkelte begivenheder - abstrakte begreber er sjældne.
Men summa: det er en virkelig god og informativ bog, der taler et klart og velskrevet sprog, hvor tolkningerne er fint legeret med realia og aldrig kommer helt ud af kontrol eller bliver fritsvævende.

Hans Jorgen Schanz

\section{Rundt om en klassiker}

David Bugge og Peter Aaboe Sorensen (red.): Livtag med Den etiske fordring, Arbus: Klim 2007, 263 s., 249 kr.

Hensigten med antologien Livtag med Den etiske fordring er at imødekomme den store interesse for Løgstrups etiske hovedværk, som har været der fra bogen udkom første gang i 1956. Løgstrups tanker om tilliden som det bærende i tilværelsen, hans pegen på interdependensen som et grundvilkår, beskrevet med den rammende formulering, at vi altid "holder noget af det andet menneskes liv $i$ vores hånd" $o g$ ikke mindst hans beskrivelse af den tavse, radikale, ensidige og uopfyldelige fordring, der giver sig af denne kendsgerning, har til stadighed interesseret både lægfolk og fagfolk på universiteter, seminarier, sygeplejeskoler, højskolekurser mv., både herhjemme og i udlandet.

Denne hensigt indfries til fulde; som læser tilskyndes man simpelthen til at (gen)læse Den etiske fordring. Antologien formår at gøre opmærksom på Den etiske fordrings bredde, dybde, originalitet og langtidsholdbarhed ved artiklernes evne til enten at zoome ind på enkelte temaer eller afsnit fra bogen eller at 
undersøge hvordan Løgstrups tanker om livssyn og etik har udviklet sig fra det tidlige forfatterskab til Den etiske fordring. Andre artikler reflekterer med afsæt i Den etiske fordring videre ved enten at sætte Løgstrups tanker i forhold til en nutidig problematik eller ved at lave et udblik til Løgstrups senere forfatterskab. Foruden de forfattere, der nævnes i nærværende anmeldelse, har følgende forfattere bidraget til antologien: Hans Fink, David Bugge, Peter Aaboe Sørensen, Svein Aage Christoffersen, Carl-Göran Heidegren og Per Nortvedt.

Kees van Kooten Niekerks bidrag "Vejen til Den etiske fordring" er velvalgt som åbningsartikel. Han gør opmærksom på det for mange oversete faktum, at Den etiske fordring, snarere end at være et ganske nyt udgangspunkt for Løgstrups etiske tænkning, er en afslutning på en lang tankeproces, der begyndte allerede i 1931, da Løgstrup skrev prisopgave om Max Schelers etik. Niekerk følger Løgstrups tænkning i de 25 år mellem prisopgaven og det, der skulle blive Løgstrups etiske hovedværk, og redegør ikke mindst for gangen i Løgstrups tanker fra at gå ud fra en kristen etik til den kontroversielle påstand i Den etiske fordring om, at der ikke gives en kristelig etik.

Dette spørgsmål har siden optaget mange og været diskuteret flittigt. To af Løgstrups elever, Svend Andersen og Ole Jensen, diskuterer det endnu, hvilket offentligheden bl.a. kunne følge med i, da de i forbindelse med det såkaldte præsteinitiativ i julen 2005 havde en meningsudveksling i Kristeligt Dagblad. Jensen fremlægger i sin artikel "Gives der stadig ikke en kristelig etik?" Løgstrups tanker om emnet i Den etiske fordring og tilslutter sig sin gamle lærers synspunkt i afvisningen af, at der skulle gives en særlig kristelig etik. Løgstrups afvisning skyldes, at for ham hører skabelsen - det, at livet er os skænket og er os skænket som noget bestemt, nemlig med interdependensen som grundvilkår, ud af hvilket fordringen om at tage vare på det af det andet menneskes liv, som vi holder $\mathrm{i}$ vores hånd, springer - til det universelle i kristendommen, modsat det specifikt kristelige: at vi i Jesu liv og forkyndelse møder tilsigelsen af Guds tilgivelse. Fordringen hører således også til det universelle i kristendommen, der kan skildres rent bumant. Blandt andet derfor findes der i Løgstrups etik ifølge Jensen potentialet til en global etik.

Andersens bidrag "Efter loven - Den etiske fordring som luthersk etik" er ikke, som Jensens artikel, et direkte indlæg i den løbende debat mellem de to. Alligevel rummer artiklen indirekte nogle svar til Jensen, idet diskussionen også handler om, hvorvidt Løgstrup i sin afvisning af en kristelig etik følger Luther eller ej. Ifølge Andersen mener Løgstrup fejlagtigt, at hans formulering af fordringen som hørende til det universelle i kristendommen, dvs. til det, der kan beskrives filosofisk, er helt på linie med Luthers tanker om den naturlige lov, hvis indhold kan sammenfattes i den gyldne regel. 
Løgstrup har dog overset, at "Luther nok går ud fra en overensstemmelse mellem kristen næstekærlighed og en handlen efter den gyldne regel, men at han ikke hævder, at de to falder sammen" (s.75). Derfor er de handlinger, som hhv. buddet om næstekærlighed og efterlevelsen af den gyldne regel giver sig udslag i, ikke de samme: $\mathrm{N}$ stekærlighedens gerninger rummer noget mere, nemlig godgørenhed og lidelse. Til dette mere kan knyttes en særlig kristelig etik, synes tankegangen at være.

At Den etiske fordring ikke kun kan diskuteres $\mathrm{i}$ et teologisk forum, men åbner for langt større perspektiver, vidner særligt antologiens tre sidste artikler om. Regner Birkelund redegør i sit, til tider noget overfladiske, bidrag for Løgstrups syn på skole og pædagogik, der også har rødder i hans etiske tænkning og skecnkethedens livsforståelse. Skolens formål er tilværelsesoplysning, ikke uddannelse, siger Løgstrup i en artikel fra 1981, skrevet kort før hans død. Dermed indskriver han tydeligvis sine tanker om skole og pædagogik i den grundtvigske tradition. Om Løgstrup tillige uproblematisk kan tilskrives "den græske opfattelse af verden som en besjælet og guddommelig indretning” (s.194), hvilket synes at være en af Birkelunds kæpheste, er dog mere tvivlsomt.

Jørn Henrik Petersen og Lis Holm Petersen viser i deres velskrevne og let tilgængelige bidrag "Gensidig eller ensidig? - Om Løgstrups etiske fordring og den danske velfærdsstats norma- tive grundlag", at der kan argumenteres overbevisende for, at "den danske velfærdsstat som idealtype [er] udtryk for den "institutionaliserede etiske fordring'"' (s.222). En konsekvens af dette er, at der pga. fordringens ensidighed; der kan ikke rejses krav om gengæld, i en velfærdsstat kun kan være tale om en pligt til at give - ikke en pligt til at modtage. Ud fra denne karakteristik af velfærdsstaten må således alle tanker om "velfærdsrettigheder" formodes diskvalificerede.

Antologien afsluttes med en fyldig artikel af Zygmunt Bauman: 'Lévinas og Løgstrup in the globalized world of consumers". Lévinas' etik med udgangspunkt i den Anden og ansigtet, også beskrevet som en nærhedsetik, ligner på mange måder Løgstrups etik og fordringen om at tage vare på det af den andens liv, vi holder $i$ vores hånd. Bauman tilslutter sig på sin vis Petersen og Petersen når han siger, at Lévinas' og Løgstrups etik, hvis indhold han sammenfattende gengiver som en "moral impulse", må nedskrives $\mathrm{i}$ regler og love, hvis den skal give mening på samfundsplan. Alligevel stiller han sig tvivlende over for, at denne form for nærhedsetik skulle kunne give svar på nogle af de udfordringer, som samfundet i dag står overfor. Dagens samfund karakteriseres dels ved at være et samfund af forbrugere, dels ved at være et globalt samfund. Forbrugersamfundets offer i etisk sammenhæng er først og fremmest den Anden: "The collateral victim of the leap to the consumerist rendition of 
freedom is the Other as object of ethical responsibility and moral concern" (s.242). Det ansvar, man som forbruger udviser, gælder ikke den Anden, men kun en selv. Således synes Bauman at mene, at Løgstrups menneskesyn - at vi i udgangspunktet altid møder den Anden med tillid - er en smule naivt, når man ser på verden $i$ dag, hvor det helt modsatte menneskesyn er dominerende: "strangers are not to be trusted" (s.245). De andre er ikke medmennesker, men først og fremmest konkurrenter: "In a game of survival, trust, compassion and mercy (the paramount attributes of Løgstrup's 'sovereign expressions of life') are suicidal' (s.246).

I det globale samfund gælder, at det enkelte menneskes handlinger ikke længere er begrænset $\mathrm{i}$ tid og rum, hvorfor de kan have uoverskuelige konsekvenser: "What we do (or abstain from doing) may influence the conditions of life (or death) of people in places we will never visit and of generation we will never know" (s.255). Globaliseringen har derfor nok skabt en større global interdependens, men desværre ikke en tilsvarende større global solidaritet. De globale udfordringer kræver globale svar, hvilket ifølge Bauman ikke kan findes i Lévinas' og Løgstrups etik. Bauman er således ikke enig med Ole Jensen $i$, at der i Løgstrups etik skulle være potentiale for en global etik.

Uanset om man er kender af Den etiske fordring eller endnu har til gode at læse den, vil Livtag med den etiske fordring være berigende for den læser, der er interesseret i etik, teologi, politik, litteratur - og alt, hvad der ligger derimellem. Herfra skal således lyde en klar opfordring til at give sig i kast med begge bøger.

Maria Lonise Odgaard Moller

\section{Arkitekturens sociale dimension}

Niels Bjorn (red.): Arkitektur der Forandrer - fra ghetto til velfungerende byomrade, Gads Forlag 2008, 24 sider, 299 kr.

Arkitektur er ikke bare neutrale containere for menneskenes liv og samliv. Arkitektur kan være meningsgivende rammer, der kan skærme, definere funktioner og understøtte individernes erfaring af egne handlemuligheder og sociale sammenhænge. Værket Arkitektur der Forandrer - fra Ghetto til velfungerende byområde har som erklæret mål at vise at sociale problemer i udsatte byområder områder kan afhjælpes gennem inddragelse af arkitektoniske løsninger i forandringsstrategierne. Bogen forsøger såvel at give researchbaserede bud på, hvad der er galt i de danske udsatte byområder, som at anvise alternative løsningsforslag hvor sociale og arkitektoniske indgreb kan understøtte hinanden.

Bogen rummer beskrivelser af de sidste 150-års byudvikling, afrapporteringer for forskellige workshops afholdt i belastede byområder i Danmark og ikke mindst, og her er en af bogens største fortjenester, inspirerende beretninger fra udenlandske løsningsmodeller. En række artikler 